exception, all the important buildings in the town have been thrown down, but, fortunately, without any outbreak of fire. The loss of life and property is not yet definitely known, as communications with the capital are almost destroyed, but, according to official estimates, 220 persons have been killed. It is feared that, as in 1835 , there may also be an eruption of the neighbouring volcano.

\section{Bushman Hybrids}

IN another column of this issue of NATURE (see p. 37) a summary is given of a short paper by Dr. T. F. Dreyer of Bloemfontein on "The Significance of the Bushman Skull", of which the importance for the anthropologist, the sociologist and in the long run possibly also for the statesman, is by no means to be gauged by its brevity. It opens up a wide vista of further research and inference on the allimportant question of miscegenation. Students of the effects of racial contact and admixture, from lack of positive and unequivocal evidence, have long hesitated to endorse the popular verdict that crossbreeds in man have the vices of both parent races and the virtues of neither. They prefer, or rather are forced, to attribute the observed defects in character of such hybrids, and especially of hybrids between white and coloured, to the environmental influence of the social conditions to which as a rule they are confined, rather than to any inherent hereditary weakness. Some, perhaps, would go so far as to concede the possibility that extreme diversity in physical make-up of two widely separated races in the parents may react unfavourably in the offspring; but on the whole, notwithstanding the results of a number of investigations, judgment has more or less remained in suspense.

DR. DREYER's study of the processes of growth which have produced the characteristic Bushman skull suggests a line of research, which, if it should yield results analogous to those observed in Bushman hybrids, will afford grounds for the conclusion that hybridization of certain types may produce specific modification of structure and function, which being abnormal, may be presumed to be unfavourable to the organism as a whole. The Bushman hybrids observed by Dr. Dreyer showed in their abnormal development in the direction of acromegaly or the reverse condition the result of a disturbance of the function of the pituitary-an inference supported by evidence that that body was either over- or underdeveloped. Should further research show this conclusion to be of general application, it will do much to remove at least one line of argument in the discussion of racial contact from the influence of racial prejudice.

\section{Bronze Age Cemetery near Glasgow}

AN important addition to the record of recent finds of prehistoric age in the neighbourhood of Glasgow is a bronze age cemetery site at Springhill Farm, Baillieston, identified and examined by Mr. J. Harrison Maxwell and other members of the Glasgow
Archæological Society. The first indication of the site was the unearthing of two food vessels in May last by workmen, when excavating a hillock for sand and gravel. Of these two vessels, one, according to a description in The Times of December 21, was in perfect condition. It was hand-made and of reddish brown clay, with two zones of decoration made by string impression, the upper zone in horizontal, the lower in vertical or slightly oblique lines. The second vessel, unfortunately broken by the workman in digging, but now skilfully restored, is of a more elaborate and beautiful character. Its rim is bevelled inward, and for ornament it has an upper zone of decoration formed by horizontal rows of impressions of barley ears, while elsewhere are impressions or punch marks made by the end of a hollow bone, stick or reed. This discovery led to a careful watch on the progress of excavation, and a number of burials, seven cremated and two inhumed, were recorded. The most important discovery, however, was that of a bronze age cist of unusual type in that instead of two long and two short stones, it is built of a large number of small stones and is tongueshaped, about four feet long and two feet broad at its greatest breadth. The cover consisted of two large stones, that to the south being very thick, while that to the north had an oblong cut-out on the east side. The floor was a pavement of water-rolled pebbles. There were two eremation burials on top of, and two inside the cist. Discoveries of bones and a burial were made in November and December, of which the latest has not yet been excavated. The bones are under examination. Two square-shaped pits containing iron slag point to the existence of a later 'bloomery' or forge.

\section{Roman Sussex}

A DIscovery of Roman remains, of interest for its topographical bearing, is reported from West Sussex. Workmen, while laying a water-main from Wickford Bridge, east of Pulborough, to Hurston Farm, discovered Roman walls of rough sandstone, and bonding courses of Roman tiles at a depth of 1-7 feet. They lay just north of Lickfold along the west side of the Wiggonholt Road. According to the account given by the workmen, as reported in The Times of December 24, two walls running parallel to the road and about fifteen feet in, formed a passage, at the end of which was a small square apartment. From the character of the red burnt sandstone and flue tiles thrown out, it is considered reasonable to infer that this had been a stoking chamber and hypocaust belonging to a house site, similar to one of which there are indications one hundred yards away. Surface finds of pottery belong to the turn of the first and second century. The importance of the find lies in the fact that it corroborates the identification of the modern road as being on the line of the Roman road from Stane Street at North Heath, Pulborough, by Wiggonholt to the South Downs north of Storrington. The great depth at which the remains were found is due, it is suggested, to the drift of light sandy soil on a down slope. 